\title{
Bacteriuria in Pregnant and Non Pregnant Women in Benghazi Acomparative Study
}

\author{
Khaled A. Almehdawi (MSc) ${ }^{1}$, Ramadan H. Ali (MSc) $)^{2}$ Faisal F. Ismail(MSc) ${ }^{3}$ \\ ${ }^{1,2}$-Ministry of Health, Benghazi, Libya \\ ${ }^{3-}$ Faculty of Medical Technology, University of Tobruk,Tobruk,Libya
}

\begin{abstract}
Background: Bacteriuria is associated with significant maternal and foetal risks. However, its prevalence is not well known in our community.

Objectives: Determine the prevalence and predictors of bacteriuria in women of the Benghazi, Libya as well as the antibiotic sensitivity patterns of bacterial isolates.

Methods: Across-sectional study was carried out amongst pregnant and non pregnant women attending many poly clinics in Benghazi. We recruited 120 consenting women (60 pregnant and 60 non pregnant) for the study. Demographic and clinical data were collected using structured questionnaire. Clean catch midstream urine was collected from each participant. Samples were examined biochemically, microscopically and by culture. Significant bacteriuria was defined as the presence of $10^{5}$ bacteria per $\mathrm{ml}$ of cultured urine. Identification and susceptibility of isolates was performed using API (BioMerieux, France Company) .

Results: Significant bacteriuria was found in the urine of $13.3 \%$ (16) of all women with prevalence of $16.7 \%$ in pregnant women. Asymptomatic bacteriuria was detected in $8.3 \%$ (10). The most frequent isolates were Staphylococcus aureus(31.2\%), Escherichia coli (25\%), Staphylococcus saprophyticus (18.9\%), and were sensitive to gentamycin (GN) 87.5\%, azithromycin (AZM)75\%, and the less effective antibiotics were cephalexine (CL) and ampicillin $(A M P)$

Conclusion: Bacteriuria is frequent in women particularly pregnant women suggesting the need for routine screening by urine culture, which would allow early treatment to avoid the complications. In addition, urinary tract infections appears to be multifactorial.
\end{abstract}

Keywords: Antibiotics, Bacteriuria, Libya, Pregnant, Urinary tract infections, Women.

\section{Introduction}

Urinary Tract Infections(UTIs)is an infection caused by the presence and growth of microorganisms anywhere in the urinary tract(1). UTI is evident when there are 105 or more of microorganisms of a single strain of bacterium per millilitre in midstream urine samples(2). UTI affects all age groups, but women are more susceptible than men, due to short urethra, absence of prostatic secretion, pregnancy and easy contamination of the urinary tract with faecal flora (3). Additionally, the physiological increase in plasma volume during pregnancy decreases urine concentration and up to $70 \%$ pregnant women develop glucosurea, which encourages bacterial growth in the urine (4)(5). Women identified with asymptomatic bacteriuria in early pregnancy have a 20-30-fold increased risk of developing pyelonephritis during pregnancy, compared with women without Bacteriuria (6). These women also are more likely to experience premature delivery and to have infants of low birth weight. Prospective, comparative clinical trials have consistently reported that antimicrobial treatment of asymptomatic bacteriuria during pregnancy decreases the risk of subsequent pyelonephritis from $20 \%-35 \%$ to $1 \%-4 \%(7)$.

Also there are associations between maternal complications of pregnancy and pyelonephritis including anaemia, amnionitis, hypertension, endometritis and preeclampsia (8). The most common pathogen involved in bacteriuria is Escherichia coli accounting for 60 to $90 \%$ of infections in women. Other bacteria involved include Klebsiella pneumoniae, Proteus mirabilis, and Pseudomonas aeruginosa (9). Gram-positive organisms like Staphylococcus saprophyticus also cause bacteriuria (10). There are several ways to diagnose UTI, but urine culture still remains the most reliable tool for its diagnosis (2). In Benghazi, Libya, the data are not yet available on the prevalence of bacteriuria (symptomatic, asymptomatic) during pregnancy. This study sought to investigate the prevalence of bacteriuria among women and to determine its relation with some possible risk factors such as age, duration of pregnancy and parity, the most common types of bacteria and the most suitable antibiotics to use. 


\section{Participants:-}

\section{Materials and methods}

This study was carried out on 120 women (60 pregnant and 60 non pregnant) attending many poly clinics in Benghazi city. Their ages ranged between 18 to 48 years with mean age(32.15).

\section{Collection of specimens:-}

Urine specimens were collected from participants in sterile containers by the mid stream urine samples. Each sample was divided into two parts. One part was used for general urine examinations, and other part was used for culture(10). Cases which had taken antibiotic during the previous two weeks were excluded. Personal information was obtained using a well structured questionnaire.

\section{Sampling and bacteriological analysis:-}

Participants were advised to collect a clean catch of 10-20 ml of midstream urine using sterile disposable leak proof containers respecting aseptic collection techniques. Aliquots of urine samples were centrifuged at 3000 rpm for 10-15 minutes. Sediment from each sample was used to streak culture media and prepare a wet mount for microscopy (9). The remainder of the urine was tested biochemically using dipsticks impregnated with leucocyte esterase and nitrite tests.The urine dipstick kit used was Medi-Test Combi 9 (Macherey-Nagel, Germany).

\section{Culture process}

Urine samples were cultured using a standard loop calibrated to hold $0.01 \mathrm{ml}$ of urine on to Blood agar, MacConkey agar and Cysteine Lactose Electrolyte Deficient (CLED) agar. Inoculated plates were incubated at $37 \mathrm{C}$ aerobically overnight.

\section{Colony counts}

Colonies were counted on CLED and multiplied by the loop volume. A bacterial count of $1 \times 10^{5}$ per ml was considered significant for UTI and counts of $10^{2}-10^{4}$ per ml were considered as suspected/doubtful bacteriuria while counts less than $10^{2}$ per $\mathrm{ml}$ were considered no significant bacterial growth (9).

\section{Bacterial identification}

Growths on the culture media were identified using their growth characteristics, Gram stain and biochemical tests which include Indole test for lactose fermenting bacteria particularly E.coli and Klebsiella and Coagulase test to differentiate Staphylococcus aureus from other Staphylococcus spp. Genera and species of bacteria were identified by using the Analytic Profile Index (API) according to the manufactured instructions of BioMerieux, France Company .

\section{Sensitivity tests}

The media used were Muller-Hinton agar (Oxoid). Antimicrobial susceptibility tests were performed using Kirby-Bauer disc diffusion test. The isolates from this study were tested against many antibiotics (Figure 2). All analytical tests have been done at the labs of Almajori poly clinics and Benghazi Center of Infectious Diseases and Immunity(BCIDI), Benghazi, Libya

\section{Statistical analysis}

The results data were entered in to SPSS program and descriptive statistic was used to summaries the data, like tables, figures, and measures of central tendency. Analytic statistics were used to compare between the variables. Chi-square $\left(\mathrm{x}^{2}\right)$ was used, significance was assumed at when $\mathrm{p} \leq 0.05$.

\section{Results}

In this study the prevalence of bacteriuria in women was found to be $13.3 \%$, in pregnant women 16.7 $\%$ and in non pregnant women $10 \%$. Asymptomatic bacteriuria in all women was 10/120 cases $8.3 \%$.This indicates that about $16.7 \%$ of pregnant women are at risk of development of acute episode of UTI during pregnancy if they are not properly treated.

Table 1. Distribution of cases by age and Bacteriuria.

\begin{tabular}{|c|c|c|c|c|c|c|}
\hline \multirow{2}{*}{ Bacteriuria } & \multicolumn{2}{|c|}{ Cases with Bacteriuria } & \multicolumn{2}{|c|}{ Cases without Bacteriuria } & \multicolumn{2}{|c|}{ Total } \\
\hline & NO & $\%$ & NO & $\%$ & $\mathrm{NO}$ & $\%$ \\
\hline Age / year & & $\bar{X}$ & 13.744 & $\mathrm{p}=0.000$ & $\mathrm{~S}$ & \\
\hline $18-24$ & 3 & 18.75 & 16 & 15.3 & 19 & 15.8 \\
\hline $25-30$ & 10 & 62.5 & 23 & 22.1 & 33 & 27.5 \\
\hline $31-36$ & 1 & 6.25 & 36 & 34.7 & 37 & 30.8 \\
\hline $37-42$ & 2 & 12.5 & 19 & 18.3 & 21 & 17.6 \\
\hline $43-48$ & 0 & 0 & 10 & 9.6 & 10 & 8.3 \\
\hline Total & 16 & 13.3 & 104 & 86.7 & 120 & 100 \\
\hline
\end{tabular}
-Mean age $=32.15$
-Median $=32$
-Mode 30
-Range $=30$
-Minimum =18
-Maximum $=48$ 
Table 2. Distribution of cases by their education level, marital status and Bacteriuria

\begin{tabular}{|c|c|c|c|c|c|c|}
\hline \multirow[t]{2}{*}{ Bacteriuria } & \multicolumn{2}{|c|}{ Cases with Bacteriuria } & \multicolumn{2}{|c|}{ Cases without Bacteriuria } & \multicolumn{2}{|c|}{ Total } \\
\hline & $\mathrm{NO}$ & $\%$ & $\mathrm{NO}$ & $\%$ & $\mathrm{NO}$ & $\%$ \\
\hline Level of Education & & & $X^{2}=5$. & $\mathrm{p}=0.147$ & & \\
\hline Illiterate & 4 & 30.8 & 9 & 69.2 & 13 & 10.8 \\
\hline Primary & 5 & 18.5 & 22 & 81.5 & 27 & 22.5 \\
\hline Secondary & 5 & 11.1 & 40 & 88.9 & 45 & 37.5 \\
\hline University & 2 & 5.7 & 33 & 94.3 & 35 & 29.2 \\
\hline Marital status & & & $X^{2}=0$. & $\mathrm{p}=0.5$ & & \\
\hline Married & 14 & 14.7 & 81 & 85.3 & 95 & 100 \\
\hline Un married & 2 & 8 & 23 & 92 & 25 & 100 \\
\hline Total & 16 & $13.3 \%$ & 104 & $86.7 \%$ & 120 & $100 \%$ \\
\hline
\end{tabular}

Table 3. Distribution of cases by their pregnancy and Bacteriuria

\begin{tabular}{|c|c|c|c|c|c|c|c|c|}
\hline \multirow[t]{2}{*}{ Bacteriuria } & \multicolumn{2}{|c|}{$\begin{array}{c}\text { Symptomatic } \\
\text { Bacteriuria }\end{array}$} & \multicolumn{2}{|c|}{$\begin{array}{c}\text { Asymptomatic } \\
\text { Bacteriuria }\end{array}$} & \multicolumn{2}{|c|}{$\begin{array}{c}\text { Cases witout } \\
\text { Bacteriuria }\end{array}$} & \multicolumn{2}{|c|}{ Total } \\
\hline & $\mathrm{NO}$ & $\%$ & $\mathrm{NO}$ & $\%$ & $\mathrm{NO}$ & $\%$ & $\mathrm{NO}$ & $\%$ \\
\hline Pregnancy & \multicolumn{8}{|c|}{$\mathrm{X}^{2}=1.754 \quad \mathrm{df}=2 \quad \mathrm{p}=0.416$ N.S. } \\
\hline Pregnant & 3 & 5 & 7 & 11.7 & 50 & 83.3 & 60 & 100 \\
\hline Non Pregnant & 3 & 5 & 3 & 5 & 54 & 90 & 60 & 100 \\
\hline Total & 6 & 5 & 10 & 8.3 & 104 & 86.7 & 120 & 100 \\
\hline
\end{tabular}

Table 4. Distribution of cases by their duration of pregnancy and Bacteriuria

\begin{tabular}{|c|c|c|c|c|c|c|}
\hline \multirow[t]{2}{*}{ Bacteriuria } & \multicolumn{2}{|c|}{ Cases with Bacteriuria } & \multicolumn{2}{|c|}{$\begin{array}{c}\text { Cases without } \\
\text { Bacteriuria }\end{array}$} & \multicolumn{2}{|c|}{ Total } \\
\hline & $\mathrm{NO}$ & $\%$ & $\mathrm{NO}$ & $\%$ & $\mathrm{NO}$ & $\%$ \\
\hline Pregnancy Trimester & \multicolumn{6}{|c|}{$\mathrm{X}^{2}=1.719 \mathrm{df}=2 \mathrm{p}=0.423$} \\
\hline First Trimester & 1 & 6.3 & 15 & 93.7 & 16 & 26.7 \\
\hline Second Trimester & 6 & 20 & 24 & 80 & 30 & 50 \\
\hline Third Trimester & 3 & 21.4 & 11 & 78.6 & 14 & 23.3 \\
\hline Total & 10 & 16.7 & 50 & 83.3 & 60 & 100 \\
\hline
\end{tabular}

$\square$ Escherichia coli
$\square$ Serratia marcescens
$\square$ Staphylococcus aureas
$\square$ Staphylococcus saprophyticus
$\square$ Enterococci
$\square$ Streptococcus pyogenus

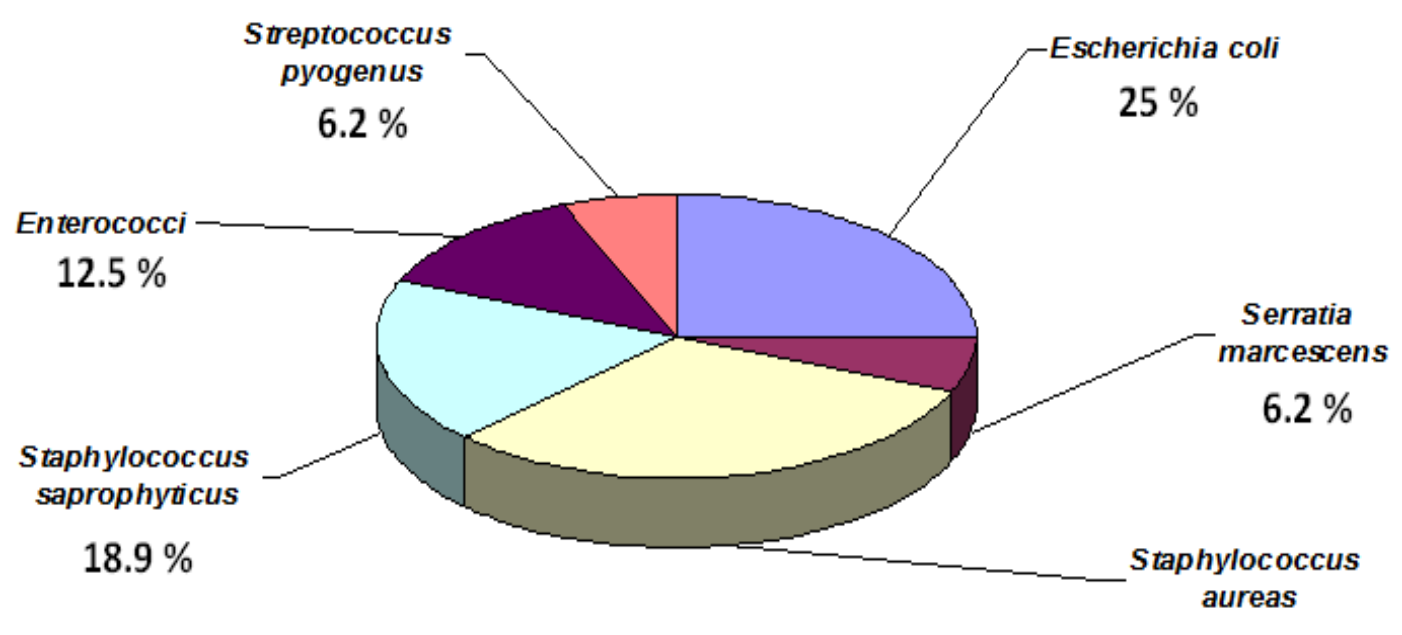

$31.2 \%$

Figure 1 The percentage isolation of bacteria responsible of bacteriuria. 


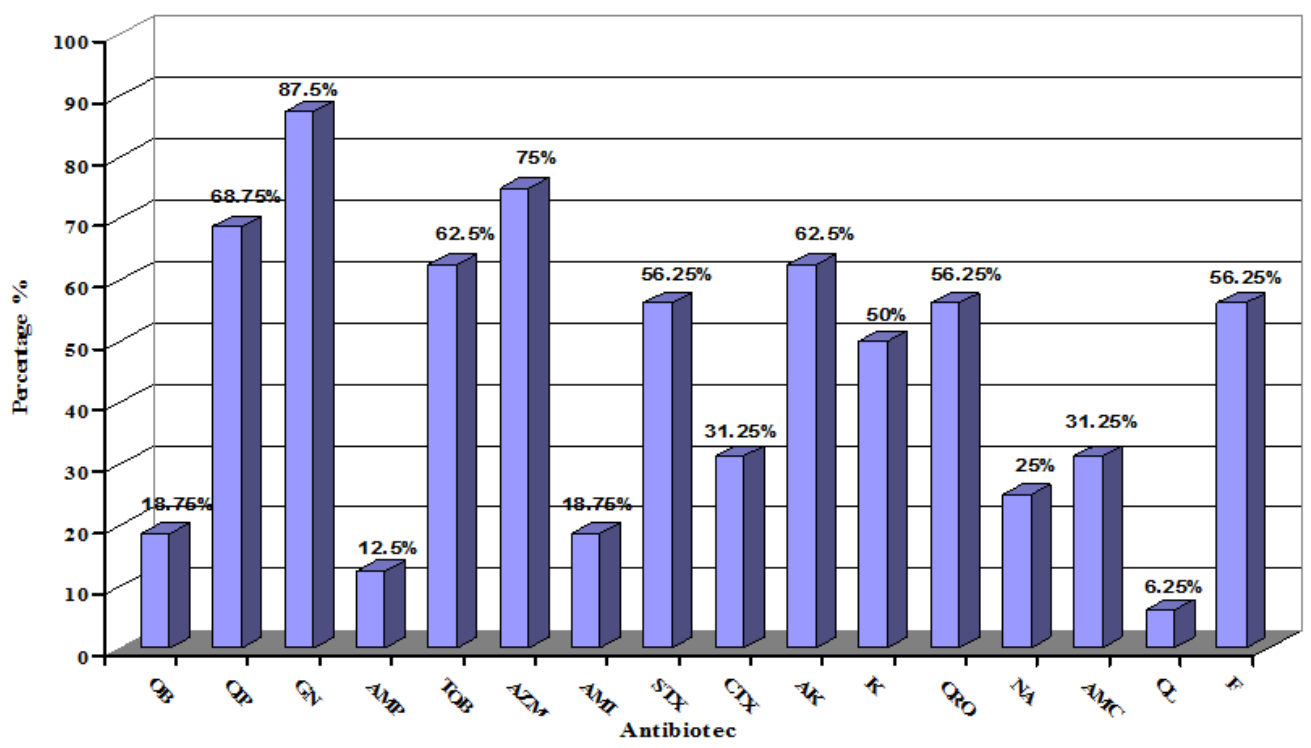

Figure 2. Effects of the Antibiotics on the bacteria

\section{Discussion}

In this study the prevalence of bacteriuria in women was found to be $13.3 \%(16 / 120)$, in pregnant women $16.7 \%(10 / 60)$, and in non pregnant women $10 \%(6 / 60)$. Asymptomatic bacteriuria in all women was $8.3 \%$ (10/120), in pregnant women was $11.7 \%$ (7/60), and in non pregnant women was 5\% (3/60). This indicates that about $16.7 \%$ of pregnant women are at risk of development of acute episode of UTI during pregnancy if they are not properly treated. These findings are similar to that of Uncu who reported the prevalence of asymptomatic bacteriuria in pregnant women $9.3 \%$ (11). In a study performed in turkey, the prevalence of asymptomatic bacteriuria was reported to be $8.1 \%$ (12).

The results of the present study found significantly high relation between age and bacteriuria $(\mathrm{p}=0.00)$ (Table 1) and revealed that the bacteriuria in women was commonest in the age group 25-30 years $62.5 \%$, and these result agreed with study by Buzayan in Libya(13), but contrast with study in Yemen that observed the bacteriuria was more in the age group 15-24 years 53.7\%(14). The difference may be due to social factors such as early age of marriage and sexual activity. There is no significant relationship between level of education and bacteriuria( $\mathrm{p}=0.147)$ (Table 2$)$, the prevalence of bacteriuria was $30.8 \%$ in illiterate, $18.5 \%$ in primary, $11.1 \%$ in secondary and $5.7 \%$ in university level of education . However, as the level of education increases there is decrease in bacteriuria among women and these findings are similar with Samad (2007) (15). The prevalence of bacteriuria was $14.7 \%$ in married women, and $8 \%$ in unmarried women, differences are founded apparently but no statistical difference $(\mathrm{p}=0.562)$ (Table 2), while Krcmery et al., showed that the risk factors for bacteriuria in women include sexual intercourse and having a marital history (16).

The bacteriuria in the pregnant women was observed more in the third trimester $21.4 \%$ than in the first trimester $6.3 \%$, and second trimester $20 \%$. But no significant $(\mathrm{p}=0.423$ ) (Table 4), Similar with Haddad who found that the bacteriuria was more in the third trimester $48.8 \%$ (14). In contrast Buzayan (1998) (13). In this study the most frequent isolates were Staphylococcus aureus (31.2\%), E.coli (25\% ), Staphylococcus saprophyticus(18.9\%), Enterococcus species(12.5\%), Streptococcus pyogenes $(6.2 \%)$ and Serratia marcescens $(6.2 \%)$ (Figure 1), where as another Libyan study found that the bacteriuria in pregnant women caused by E.coli $65.5 \%$ and Klebsiella pneumonia 20.7\% (13), and Haddad found E.coli was most frequently isolated 41.5\%, followed by Staphylococcus aureus $19.5 \%$ (14). The result of this study agreed with that of Oyagade et al., (2004), who found that the microbiological culture of urine samples from 502 pregnant women resulted in the isolation of bacteria, which were Staphylococcus aureus 21.3\%, E.coli 16.0\%, Staphylococcus spp 14.7\% (17). The most effective antibiotics tested on the isolated bacteria were gentamycin (GN) $87.5 \%$, azithromycin (AZM) 75\% and ciprofloxacin (CIP) 68.75\%, and the less effective antibiotics were cephalexine (CL) $6.25 \%$, and ampicillin (AMP) 12.5\%. The results of this study agreed with other studies which stated that urine culture is the gold standard method of diagnosis for bacteriuria .It is shown that urine dipstick testing for nitrite ,urinalysis, and enzymatic urine screening tests can poorly detect all the culture positive bacteriuria cases in women (15) (18) . 


\section{Conclusion}

The results of this work supported indirectly the hypothesis there is an association of bacteriuria with age and gravidity. In addition, UTI infections appears to be multifactorial. A screening for bacteriuria in women especially pregnant women must be done to discover the infected cases, which would allow early treatment to avoid the complications. Acknowledgements We would like to thank my supervisor professor Khaled M.Hassanein, professor Tunis M.Meidan, Ms Muna M. Buzayan, Mr Mukhtar El Gazwi for thire help in this work

\section{References}

[1]. Ebie MY, Kandakai-Olukemi YT, Ayanbadejo J and Tanyigna KB (2001) Urinary Tract Infections in a Nigerian Military Hospital: Nig. J.Microbiol:15 (1): 31-37.

[2]. Bloomberg B., Oslen B., Hinderaker S., Langeland N., Gasheka P., Jureen R., Kvale G. and Midtvedt T. (2005) Antimicrobial resistance in urinary bacte-rial isolates from pregnant women in rural Tan-zania, implications for public health. Scand. J. Infect. Dis 37, 262- 268.

[3]. Awaness AM, Al-Saadi MG, Aadoas SA. (2000) Antibiotics resistance in recurrent urinary tract infection. Kufa medical journal,2000, 3:159.

[4]. Patterson TF, Andrriole VT. (1987) Bacteriuria in pregnancy. Infect Dis Clin North Am. ;1:807-822.

[5]. Lucas MJ, Cunningharm FG. (1993) Urinary tract infection in pregnancy. Clin Obstet Gynecol , 36: 855-68.

[6]. Nicolle LE. Screening for asymptomatic bacteriuria in pregnancy. In The Canadian guide to clinical preventive health care. The Canadian Task Force on the Periodic Health Examination, ed. Ottawa: Canada Communication Group, 1994:P100-6.

[7]. 60 Smaill F. Antibiotics for asymptomatic bacteriuria in pregnancy. Cochrane Database Syst Rev 2001; 2:CD000490.

[8]. Shieve LS, Handler A, Hershow R, Persky V, Davis F. (1994) Urinary Tract Infection during pregnancy: Its Association with Maternal Morbidity and Perinatal outcome. Am J Public Health 84(3): 405-410.

[9]. Moges AF, Genetu A, Mengistu G (2002) Antibiotic sensitivities of common bacterial pathogens in urinary tract infections at Gondar hospital, Ethiopia. East Afr Med J, 79(3): 140-142.

[10]. Cheesbrough M (2006) District laboratory practice in Tropical Countries Part 2.2nd Ed. New York: Cambridge University Press.

[11]. Uncu .Y; Uncu. G; Esmer. A and Bilgel .N. (2002) Should asymptomatic bacteriuria be screened in pregnancy? Clin. Exp. Obstet. Gynecol. 29:281-5.

[12]. Tugrul. S; Oral .O; Kumru. P; Kose .D; Alkan. A and Yildirim .G.( 2005).Evaluation and importance of asymptomatic bacteriuria in pregnancy. Clin Exp Obstet Gynecol.32:237-40.

[13]. Buzayan Muna Mohamed. (1998) Astudy of bacteriuria during pregnancy in Benghazis women . Benghazi university. (Unpublished thesis)

[14]. Al-Haddad A.M. (2005) Urinary tract infection among pregnant women ,Eastern Mediterranean Health Journal ,Vol 11 No 3:505510.

[15]. Samad Hazhir.(2007) Asymptomatic bacteriuria in pregnant women, Urology Journal Vol 4 No1.

[16]. Krcmery.S; Hromec .J and Demesova .D. (2001) Treatment of lower urinary tract infection in pregnancy. Int J Antimicrob Agents, 17(4):279-82.

[17]. Oyagade AO; nSI Smith; and O Famurewaf.. (2004) Asymptomatic significant bacteriuria among pregnant women in ADO-EKIT Ekit Sstate , Nigeria , African Journal of Clinical and Experimental Microbiology Vol.5,No.1.

[18]. Teppa.RJ and Roberts.JM. (2005).The uriscreen test to detect significant asymptomatic bacteriuria during pregnancy. J Soc Gynecol Investig. 12:50-3. 